\title{
Disabilities, gender and employment: social exclusion, employment equity and Canadian banking ${ }^{1}$
}

\author{
KIM ENGLAND \\ Department of Geography, University of Washington, Seattle, WA 98195, USA (e-mail: england@u.washington.edu)
}

People with disabilities, especially women, suffer from appallingly high rates of poverty, and paid work is frequently cited as a primary route out of poverty. I draw on feminist analyses of work and disability studies to reflect on the Canadian federal government's Employment Equity Act. I use the example of the 'Big Six' banks to investigate the numerical representation and occupational distribution of women and men with disabilities compared to their counterparts without disabilities. However, social justice in the workplace is at least as much about the quality of social relationships as it is about statistical effects. Reaching workplace equity also involves the creation of a workplace climate where people with disabilities experience supportive and responsive supervision, along with a sense of being respected and valued. I assess the banks' progress towards identifying and eliminating discriminatory disabling barriers. I close with a discussion of workplace climate and locate the Act in the context of a broader network of change that includes challenging ableism.

1 Thanks go to Sarah Starkweather and Elizabeth Whitford for research assistance, and Maria Fannin for the French translation. I am grateful to the 'Statistical Officers' at HRDC for processing the data for me, and to Vera Chouinard and Valorie Crooks for their patience and their comments (and those of the reviewers) on an earlier version of this paper.
Les personnes handicapées, particulairement les femmes, souffrent des taux de pauvreté très élevés. L'emploi rémunéré est frequemment cite au moyen primaire du sortir de la pauvreté. J'emploie les analyses féministes du travail et les études des personnes handicapées à réfléchir à la Loi sur l'équité en matière d'emploi du gouvernement fédérale. J'utilise l'exemple des banques 'Big Six' pour étudier la représentation numérique et la distribution du travail pour les femmes et les hommes handicapés, par rapport au leurs homologues sans handicaps. Outre les effets statistiques, la justice sociale au lieu du travail est aussi défini par la qualité des relations sociaux. L'équité au lieu du travail comporte la création d'un environnement dans lequel les personnes handicapées experience la supervision soutenue et réceptive, avec le sens d'être respectées et bien estimées. J'évalue le progrès des banques vers l'identification et l'élimination des obstacles discriminatoires. Je conclus avec une discussion de l'environnement du lieu du travail et met la Loi dans le contexte d'un plus large réseau du changement qui inclut la lutte contre la discrimination fondée sur la capacité physique.

The Canadian Geographer / Le Géographe canadien 47, no 4 (2003) 429-450

(C) / Canadian Association of Geographers / L'Association canadienne des géographes 
At present, the track record for ensuring equity for persons with disabilities, much less those with psychiatric disabilities, is far from shining. According to the 2001 Employment Equity Report, persons with disabilities represent 2.4 percent of the workforce, drastically below the labour market availability of 6.5 percent. The representation of persons with disabilities fell this year, continuing a declining trend that started in 1996. This group has experienced the least progress under the Act. (Wendy Steinberg, Policy Analyst, Canadian Mental Health Association).

Wendy Steinberg's comments are part of the evidence she gave in February 2002, before the Standing Committee on Human Resources Development and the Status of Persons with Disabilities as part of the comprehensive review of the federal Employment Equity Act for the House of Commons (Longfield 2002). People with disabilities suffer from appallingly high rates of poverty, and paid work is frequently cited as a primary route out of poverty. However, many people with disabilities, who are in paid employment, are ghettoised into low status, low paid jobs. Canada's disability policies increasingly address how and why persons with disabilities are disadvantaged in, and excluded from, the paid labour force. In this paper, I focus on a key piece of Canada's disability and employment policies: the federal government's Employment Equity Act (first passed in 1986, then amended in 1995). The Act is intended to encourage organisations to improve their employment practices regarding four 'designated groups': women, persons with disabilities, visible minorities and Aboriginals. The Act covers the federal public sector and federally regulated private firms in banking, communications and transportation. I look at the 'Big Six' banks, which are among the biggest private sector employers in Canada, and employ a substantial share of the workers covered by the Act.

Canada's national system of banks is dominated by the 'Big Six' banks (Bank of Montreal, Bank of Nova Scotia, CIBC, National Bank, Royal Bank and Toronto-Dominion Bank), which together employ 91 percent of all bank workers in Canada. My interest in the 'Big Six' stems from their prominence in the Canadian imaginary of 'Corporate Canada', especially given that the U.S. controls so much of the Canadian economy, particularly manufacturing (Britton 1996; Burgess 2000). The analysis for this paper is part of a larger, ongoing project investigating the employment of the four 'designated groups' in the 'Big Six' banks, here I explore employment by gender and disability status (women with disabilities, women without disabilities, men with disabilities and men without disabilities). I analyse the employment patterns for Canada as a whole, as well as Toronto because of its place in Canada's urban and economic hierarchy, especially in terms of financial services. In 2001, 38 percent of all 'Big Six' workers in Canada were located in Toronto (whereas the 2001 Census data indicates that 16 percent of Canada's employed workforce is in Toronto).

My paper is framed around the growing literature on the social and cultural dimensions of workplace dynamics and the role of gender in the workplace and the organisation of firms. My analysis is informed by disability studies and feminist scholars' analyses of paid work. Disability scholars generally start from a position of problematising society rather than pathologising the individual disabled person. Disability scholars examine the social, economic and political factors that marginalise people with disabilities from workplaces, communities and society. They press for the inclusion and integration of people with disabilities, including access to the labour market and the workplace. A long-standing topic of feminist investigations is gender inequality in employment, especially occupational segmentation and the gender wage gap. Those interventions have been joined by recent scholarship exploring the gendering of work, and the ways masculinities and femininities are constructed in and through the workplace. In this paper, I draw on these contributions to examine the progress towards the employment equity of persons with disabilities in the 'Big Six' banks. Following a review of the literature, I offer a reading of the Employment Equity Act through the lenses of social exclusion and civil rights discourses. Then I turn to my case study of the 'Big Six', investigating the numerical representation and occupational distribution of persons with disabilities within the banks. I then look at the banks' efforts to identify and eliminate discriminatory barriers and put in place policies aimed at achieving equity. I close with a discussion that assesses the success of the Act, and positions employment equity as part of a broader network of change, including addressing ableism. 


\section{Inequalities, Employment Barriers and 'Disabling' Workplaces}

In Canada, as in other countries, there are profound material inequalities between those with and without disabilities. More than two decades worth of studies indicate slight improvement in the everyday material conditions of people with disabilities in Canada, although some see the conditions actually worsening (Rioux 1985; D'Aubin 1987; Ross and Shillington 1990; Roeher Institute 1993, 2001; Fawcett 1996, 2000; Chouinard 1999, 2001; HRDC 2000). People with disabilities, especially women, suffer higher rates of poverty and unemployment than people without disabilities. Women with disabilities are poorer than both men with disabilities and people without disabilities. Gail Fawcett (2000) found that in 1995, 36.2 percent of working-age women with disabilities lived in poverty (twice the rate for women without disabilities18.5 percent). The equivalent figures for men were 34.1 percent and 15.6 percent for those with and without disabilities respectively. Disabilities then, double the likelihood of living in poverty. Fawcett argues that the 'best defence against poverty for persons with disabilities is employment... (but)... women with disabilities also have one of the lowest rates of labour force participation of any group of adults'. Enabling women access to better jobs is one of her main proposals for improving the economic security of persons with disabilities. ${ }^{2}$

The first comprehensive statistical data sets about the daily lives of people with disabilities in Canada were the 1986 and 1991 Health and Activity Limitation Survey (HALS) which asked people with disabilities about a wide range of social and economic issues, including their participation in society. ${ }^{3}$ The

2 The others are delinking disability-related supports from income support/replacement programs (see also HRDC 2000); restructuring income support programs that enable persons with disabilities to move in and out of paid work; and improving access to education and training to enable persons with disabilities to be more competitive in the job market.

3 The HALS was gathered with the 1986 and 1991 Census as a postcensual survey. Statistics Canada conducts very few post-census surveys; their function is to gather data on specific populations or issues. It was hoped that the HALS would be updated with each Census, but funding was cut for the 1996 Census. However, a post-census survey was conducted with the 2001 Census. The Participation and Activity Limitation Survey (PALS) was funded by Human Resources Development Canada and conducted by Statistics Canada. As I write (February 2003) the first results are being released, but the labour force data are not yet available.
1986 and 1991 HALS are a critical part of implementing the Employment Equity Act. The Act requires the organisations under the federal jurisdiction to compare their proportions of the four 'designated groups' to specified benchmarks (the current labour force availability of those groups in the general labour force according to the most recent Census). For persons with disabilities the labour force availability benchmark currently used is the 1991 HALS, which indicates that 6.5 percent of Canada's labour force has a disability (so an equitable workplace is one where 6.5 percent of the workers have disabilities). Once the 2001 Participation and Activity Limitation Survey (PALS) data are available, there will be a new labour market availability benchmark (which may well be higher than 6.5 percent). The 1991 HALS showed that 12.4 percent (2.3 million) of the working age population had a disability. Of those 2.3 million, only 48.2 percent were employed, 8.1 percent were unemployed and a huge 43.4 percent were not in the labour force. These compare with rates among the non-disabled working age population of 73 percent employed, 7.9 percent unemployed and 19.1 percent not in the labour force. The Employment Equity Act does not require the category 'persons with disabilities' to be broken down by gender (nor type or severity of disability), however, among persons with disabilities, women are much less likely to be in the labour force than men. For instance, the 1991 HALS indicates that 40.7 percent of women with disabilities are employed, 7.8 percent are unemployed and 51.5 percent are not in the labour force. That compared with 55.8 percent of men with disabilities who are employed, 8.4 percent are unemployed and 35.8 percent are not in the labour force. While the HALS data are used for official benchmarking purposes under the Employment Equity Act, there are more recent data that show continued substantial 'disability' gaps in labour force participation rates (Bunch and Crawford 1998; HRDC 2000; CCSD 2000, No. 2, No. 8). For instance, 1995 data show that women with disabilities continue to have lower labour force participation rates (38 percent) than women without disabilities (49 percent), men with disabilities (76 percent) and men without disabilities (91 percent) (HRDC 2000).

I approach the workplace as an important site of power, one where subjectivities, power and knowledge are discursively (re)produced. Thus, unemployment and the lack of access to jobs faced by 
persons with disabilities also exclude them from a critical location of power. The workplace has come under greater scrutiny in recent years. For instance, the growing scholarship on the body at work emphasises embodied workplace practices (McDowell 1997; Longhurst 2001). Embodied work includes the workplace strategies adopted by people with disabilities to manage their 'body troubles' (Moss and Dyck 1996, 1999; Kitchin, Shirlow and Shuttleworth 1998; Dyck 1999). That work is embodied also influences practices around the spatial divisions of labour within a workplace and which bodies get associated with, or are deemed most appropriate for particular types of work (Boyer 1997; Liepens 1998; Bertham and Shobock 1998; Tonkin 2000). Some bodies disrupt accepted notions of 'appropriate' embodied employment and are constructed as 'out of place' in the workplace (Boyer 1997; McDowell 1997; Kitchin 1998; Kitchin, Shirlow and Shuttleworth 1998). As Edward Hall $(1999,148)$ argues, people with disabilities are "seen as "out of place" in most workplaces, their presence disrupting accepted notions of embodied employment'.

Canada's current disabilities policies focus on 'barriers' facing persons with disabilities. Removal of barriers and increasing social inclusion is central to the federal Employment Equity Act, at least as it has been implemented in more recent years. Disabilities scholars frequently append 'ableist' to barriers-'ableist barriers'-firmly connecting the existence of barriers with social systems, and practices that exclude people with disabilities from fully participating in society and prevent them from fully exercising their civil rights (Driedger 1989; Oliver 1996; Kitchin 1998; Shakespeare 1998; Chouinard 1999). Geographers have looked at design and architectural barriers facing people with disabilities. They argue that the social and economic exclusion of people with disabilities is literally built into space, and that space is socially produced to disadvantage people with disabilities (Imrie 1996; Kitchin 1998; Kitchin, Shirlow and Shuttleworth 1998; Gleeson 1999; Parr and Butler 1999; see Fougeyrollas, Noreau and St-Michel 1997 for a rehabilitation medicine take on a similar argument). As Rob Imrie $(1996,12)$ puts it, 'the marginalisation of disabled people from the workplace often has little to do with their impairments but is more likely to be related to an inaccessible built environment'. For instance, accessible and more convenient public transportation is often one of the main accommodations that persons with disabilities say would enable them to more fully participate in society, including being in paid employment. Difficulties actually getting to a job (or even the interview!) discourage some persons with disabilities from actively seeking employment (Bunch and Crawford 1998; Kitchin, Shirlow and Shuttleworth 1998; Hine and Mitchell 2001; HDRC 2000). Exclusion from the labour market can also be because of spatial barriers within the workplace. For instance, a job promotion located in an inaccessible building, or the organisation does not have technology (e.g., voice synthesisers or TTY) that would enable people with disabilities to easily do the job. And, of course, barriers exist at the scale of poorly designed workstations. Kitchin, Shirlow and Shuttleworth $(1998,797)$ capture the outcomes of some of these barriers in their study of Donegal, West Ireland:

(workplace) inaccessibility restricted the pool of jobs which disabled people could realistically apply for, unfairly limited their work and promotion chances once employed, and may lead to the quitting of jobs if inaccessibility was leading to ill-health, further reinforcing ableist notions of disabled people in work as unable to cope.

Ableist barriers also include discriminatory and pejorative attitudes and practices. Iris Young's (1990) notion of cultural imperialism and Nancy Fraser's (1997) idea of cultural domination capture the many ways ableist solipsism results in pejorative attitudes towards people with disabilities. Dominant groups (in this instance, people without disabilities) define their experience as universal, and (often without noticing, itself an indication of power and privilege) project their own experience as representative of everyone's experience. Several empirical studies show that the ableist attitudes of employers are the most significant barrier that women with disabilities face in getting and keeping a job (DAWNOntario 1990; DAWNCanada 2001; Jongbloed 1996; Fawcett 2000). Persons with disabilities face high rates of employment discrimination when looking for a job. For example, 61.2 percent of those with moderate and severe disabilities believe that they have been denied jobs because of their disability (Roeher Institute 
1993). Recent research by the disability research section of the Canadian Council on Social Development (CCSD) suggests that people with disabilities tend to have slightly higher rates of 'involuntary' part-time employment than do those without disabilities (CCSD 2002, No. 5). Certainly women with disabilities are less likely to work full-time and all year than the other groups (14 percent, compared with 23 percent of men with disabilities, 38 percent of women without disabilities and 58 percent of men without disabilities) (HRDC 2000). And CCSD found that people with disabilities face poorer job and economic security than do those without disabilities. In a 2000 survey, CCSD found that people with disabilities, especially women, were more fearful of losing their job in the next year than were people without disabilities (CCSD 2002, No. 8).

In the workplace, employers' and managers' attitudes are a significant barrier to persons with disabilities gaining access to training, meaningful work and job promotions (and pay increases). Unsympathetic, uninformed and unsupportive employers contribute to institutionalised discrimination, disabling workplaces and social exclusion (Raskin 1994; Consultation Group on Employment Equity for Women 1995; Kitchin, Shirlow and Shuttleworth 1998; Klinger 2002). Similarly, the attitudes of co-workers towards workplace accommodation and employment equity contribute to the sense of (or lack of) an equitable workplace (Colella 2001). In their assessment of the Act, Poole and Rebick (1993, 350) point out that women 'state that harassment, whether based on sex, class or disability, is one of the most difficult aspects of their work. Even if women are hired, the climate in a workplace can ensure that they will not stay, or if they stay, that they will not be promoted'. Barriers within the workplace also include misperceptions regarding accommodating people with disabilities. Nearly 70 percent of people with disabilities do not need extensive (or expensive) accommodations in order to work, and the employment rates among this group are relatively high (about 57 percent) (Thornton and Lund 1997). ${ }^{4}$ In fact, surveys of people with disabilities not in the labour force routinely reveal that by far the most useful accommodation for them is modified days or time at work,

4 The employment rate among people who do require more extensive supports is 29 percent (Thornton and Lund 1997). and job redesign (modified duties) (Thornton and Lund 1997; HRDC 2000). In 1997 the amended federal Human Rights Act makes the duty to accommodate people with disabilities legally enforceable. Yet there continues to be a misperception that when workplaces and workstations need to be adapted to accommodate a person with a disability, it is very costly (this seems to be an argument often mobilised during periods of economic slowdown). But on average such accommodations cost less than $\$ 1,000$ (Stein 2000; HRDC 2000). These misperceptions surely lead some employers to not hire persons with disabilities (and so avoid having to even deal with accommodating them).

A long-standing concern among feminists and disabled activists and advocates is the crowding of women and persons with disabilities into low status, low paid jobs. Women and men with disabilities are under-represented in managerial and professional positions and over-represented in unskilled clerical/sales and manual labour jobs, relative to their counterparts without disabilities (Raskin 1994; Jain and Verma 1996; Fawcett 2000). This is especially the case for women with disabilities, reflecting the gendered occupational segregation evident across the labour force as a whole (Reskin 1993; Blau, Ferber and Winkler 2002; Fortin and Huberman 2002). CCSD analysed patterns of social mobility among non-managerial workers and professional/managerial workers for the period from 1993 to 1998 . They found that while occupational mobility was fairly limited for all groups of workers, those with disabilities throughout the entire six-year period were most likely to remain in non-management jobs, while upward mobility was most likely for those without a disability. They concluded that '(w)hile these data do not capture more detailed mobility patterns, particularly within the non-managerial worker group, they do provide evidence that those affected by disability are much less likely to be in positions of authority or enjoy the autonomy typically associated with professional occupations' (CCSD 2002, No. 5: 6). Finally, there are distinct earning differences by gender and disabilities. Women with disabilities typically earn less than women and men without disabilities and men with disabilities: in 1995 on average, women with disabilities earned $\$ 13,425$, women without disabilities earned $\$ 18,008$, men with disabilities earned an average of $\$ 22,129$ and 
men without disabilities earned \$30,000 (HRDC 2000; also see CCSD 2002, No. 4).

The dynamics of the everyday social practices (formal and informal) in the workplace and work relations among colleagues and with supervisors and managers can serve to reinforce gender inequalities at work (McDowell 1997; Halford, Savage and Witz 1997). The social and cultural dimensions of workplace dynamics also shape the ways in which subjectivities are forged in and through work (McDowell 1997; Liepens 1998; Bertham and Shobock 1998; Tonkin 2000). Extending these ideas to consider disabilities, Isabel Dyck $(1999,133)$ argues that '(w)orkplaces are recursively implicated in the reconstitution of subjectivity as women become defined as "disabled"'.

Here I find the scholarship on 'gendered organisations' useful, especially once it is complexified by disability status (and other social identities). That organisations are gendered (and disabling) is crucial to the (re)formulation of workplace cultures, structures, relationships and everyday practices (see especially Kanter 1977; Acker 1990, 2000; Aaltio and Mills 2002; Wilson 2003). Joan Acker (2000) argues that what she calls the 'gendered archaeology' of organisations are (re)produced in ways that privilege hegemonic masculinities. Organisations perpetuate very specific values and practices that structure the collections of unquestioned, 'appropriate' and 'reasonable' ways to work. Although organisations can no longer say that women (or persons with disabilities) are not appropriate for specific jobs, the 'gendered archaeology' of past actions lingers. Social networks, 'shared' understandings, informal practices and conventions of inclusion and exclusion can operate to reinforce dominant and subordinate places in the organisation. So supposedly neutral formal policies and practices can work to privilege certain groups of people over others. Mary Klinger (2002) considers organisational culture from the perspective of persons with disabilities. She points out that most organisational cultures were established before persons with disabilities attempted to achieve workplace equity meaning that existing cultures and prejudicial attitudes make the inclusion of under-represented groups difficult. Klinger (2002, 22, emphasis added) problematises the expectation that new hires assimilate: (it) is difficult enough for anyone new to a job, but it may be an insurmountable task for someone who is perceived as different and is not acknowledged by the culture.... The burden needs to be placed on the organization rather than on the new employee. There needs to be a way to recognize diversity as an asset in organizations so that under represented populations can become part of the culture.

Acker's concept of the gendered archaeology of organisations can be adapted to investigate the 'disabling archaeology' of workplaces. Organisational power is an ongoing process, thus one strategy for eroding gendered and disabling archaeology is to have more women and people with disabilities in positions of power to influence meaningful organisational change (Raskin 1994; Agocs 2002). As Audrey Kobayashi points out 'progress in breaking down barriers is part of creating the kind of hiring practices that will see more members of designated groups hired and promoted, the rate of cultural change is hastened once the numbers begin to shift' $(2002,246)$.

\section{Disabilities, Social Policy and Civil Rights}

The Employment Equity Act addresses systemic employment discrimination faced by the four designated groups (women, persons with disabilities, visible minorities and Aboriginal peoples). The Act was developed on the basis of the Abella Report (1984) which found that the four designated groups persistently suffered disadvantage in paid employment, including higher unemployment rates, limited opportunities for permanent full-time, well-paid jobs and limited access to positions of decisionmaking power, for instance, management positions involving corporate policy making and strategic planning. The intention of the Act is to eliminate barriers to the designated groups' access to jobs, and once employed increase their retention and promotion rates, and to reduce occupational ghettos. The purpose of the Employment Equity Act is to:

achieve equality in the work place so that no person shall be denied employment opportunities or benefits for reasons unrelated to ability and, in the fulfillment of that goal, to correct the conditions of disadvantage in employment experienced by [the designated groups] by giving effect to the principle 
that employment equity means more than treating persons the same way but also requires special measures and accommodation of differences (Section 2 of both the 1986 and 1995 Act).

The Employment Equity Act also stipulates that employers implement employment equity by 'identifying and eliminating employment barriers against persons in designated groups that result from the employer's employment systems, policies and practices that are not authorized by law' (Section 5).

The Act covers crown corporations, federally regulated employers (with at least 100 employees) in the banking, transportation and communications sectors, and federal public service (added under the 1995 Act). ${ }^{5}$ Employers covered by the Act are obliged to conduct annual audits. These involve a statistical 'workforce survey' to compare the statistical representation of the designated groups among their workers to the availability of the four designated groups in the general labour pool (according to the latest Census data available, for persons with disabilities it is 6.5 percent). Organisations collect several types of data for all workers and also separately for each of the four designated groups: specifically they report their total workforce, and the number of people promoted, hired and 'terminated' (a worker who retired, resigned, was laid off or dismissed). All these data are required to be broken down by gender and occupation. ${ }^{6}$ The annual audit

5 In 2001, the Act covered about 420 private sector companies and crown corporations, employing about 635,000 people. The federal public service added another 219,000 people working in about 80 federal government departments and special operating agencies (such as Parks Canada). Accompanying the 1986 Act was the Federal Contractor's Program for Employment Equity introduced to oblige companies (with 100 or more employees) bidding for government contracts of at least $\$ 200,000$ to have employment equity policies in order to win the contract (the companies are mainly in manufacturing and services such as engineering, university research and cleaning services). In 2001 the Federal Contractors Program involved about 800 companies with 1.15 million workers. This and the Employment Equity Act account for about 12 percent of the employed labour force.

6 The employment equity data currently do not identify women who face 'triple jeopardy', for instance women of colour with disabilities (nor are men of colour with disabilities identified). One recommendation in the recent review of the Act is that such data be collected (Longfield 2002). More generally both activists and employers (especially the banks) have long criticised the definition of 'persons with disabilities' for the purposes of the Employment Equity Act. The definition was slightly modified with the 1995 amendment, and was a key issue in the 2001 review (Longfield 2002). also includes conducting an 'employment systems review' of their human resource policies and practices to identify and eliminate barriers against the designated groups. The organisations' reports must include a narrative evaluating their progress towards their previously reported employment equity goals, and their future goals for implementing further policies and practices to remove employment barriers. Employers are required to provide the statistical data and their narratives to HRDC. An Annual Report is submitted to Parliament that summarises the employers' reports. The Annual Report is, in turn, released to the public.

There are three central components of the Act. First, numerical representation of the designated groups in an organisation should reflect their availability in the labour market (the benchmarks for each of the designated groups). Second, within an organisation the occupational distribution of the designated groups, along with their promotion and termination rates should reflect those of the majority group. Progress towards these two goals is monitored by the annual audit data. The 'employment systems review' relates to a third component of the Act: identifying and eliminating discriminatory barriers and exclusionary policies and practices that result from the employers' employment systems, policies and practices that are not authorised by law. Exclusionary policies and practices limit the designated groups' access to jobs, accommodation, career development and promotions. The Act explicitly allows for 'special measures and accommodation of differences' to address these goals (Section 2 of both the 1986 and 1995 Act).

A recent trend in social policy is addressing 'social exclusion' which makes explicit the material conditions and outcomes of the exclusion of certain groups, like persons with disabilities, from mainstream society (Gordon 2000; Hills, Burchardt and Piachaud 2002; Barnes, Heady, Middleton and Millar 2003). Generally, concerns about high rates of poverty are the main focus, but increasingly consideration is given to access to paid employment, the legal system and the formal political system. Pivotal to recent policy formulations is the elimination of barriers contributing to the exclusion of people with disabilities, along with social, architectural and technical supports enabling people with disabilities to become independent, full citizens in all aspects of society. The 
discourse in disability policy formulation increasingly points to all segments of society being complicit in the exclusion of people with disabilities, and thus sharing responsibility for reaching the goal of inclusion (Jongbloed 2003; Roeher Institute 2001; see HRDC 2000 for one example, and recent speeches from the Throne). In particular the inclusion of people with disabilities in paid employment is central to the ongoing development of Canadian disabilities policy.

Activism and rights-based politics have also been pivotal in shifting the discourses and practices around persons with disabilities towards social inclusion. Over a decade ago Diane Dreidger (1989) described disability rights activism as 'the last civil rights movement' (see also Jongbloed 2003). And Vera Chouinard $(2001,187)$ argues 'disabled Canadians have struggled against daunting odds to advance and assert rights to be included and participate in the same spaces of life as other citizens'. Disability rights activists, advocates and research units in Canada (such as the Council of Canadian with Disabilities, the Canadian Council on Rehabilitation and Work and the Roeher Institute) have long used civil rights discourses in their efforts to affect change. Some scholars describe the social model of disabilities as the 'civil rights model of disabilities' (Neufeldt and Friio 1995; Waddington and Diller 2000). Canada's current disabilities policies are increasingly infused with a civil rights flavour. They are replete with language about ensuring the equality, inclusion and the full participation of persons with disabilities. Waddington and Diller $(2000,2)$ productively tie together the social/civil rights model of disabilities, social exclusion and disability policies by suggesting:

(the) civil rights model rejects the premise that social exclusion is an inevitable consequence of disability. Under this view, people with disabilities have historically been excluded from social institutions because those institutions have failed to adapt to the needs of the disabled in the same ways that they routinely adapt to the needs of others.... Seen in this light, the problem is one of discrimination, rather than the inherent medical limitations imposed by disability. Under the civil rights model, the goal of disability policy is to reform mainstream social institutions to include people with disabilities, rather than to maintain a parallel track.
Moreover, as the non-disabled majority gain increasing contact with people with disabilities, prejudice may abate and the necessity for legal intervention may diminish.

I find Waddington and Diller's framing useful in interpreting the Employment Equity Act. Adapting their words to the Act then: persons with disabilities have historically been excluded from many workplaces because organisations (as social institutions) fail to adapt to the needs of persons with disabilities to the extent they adapt to the needs of others. The problem is discrimination, rather than the inherent medical limitations of persons with disabilities. The goal of the Employment Equity Act is to reform employers to include people with disabilities and to redirect explanations of the exclusion of persons with disabilities around the failure of organisations to adapt to their needs. Thus the burden is placed on the organisation rather than the person with a disability. Perhaps (and hopefully) as the non-disabled majority gain increasing contact with people with disabilities, hopefully prejudice may abate and the necessity for legal intervention may diminish.

However, assessments of the banks' performance regarding persons with disabilities, especially in the early years of the Act, suggest at best, limited success (Poole 1990; Poole and Rebick 1993; Kerzner and Baker 1999). Those assessments are also reflected in Wendy Stienberg's comments opening my paper, 'the track record for ensuring equity of persons with disabilities... is far from shining'. Other assessments of the Act also suggest that while so far tangible results are limited, they are more marked among women (as a group) and visible minorities than among Aboriginals and persons with disabilities (Bakan and Kobayashi 2000; Agocs 2002; England and Gad 2003). This unevenness was a persistent theme among those presenting evidence before the 2001 review committee of the Act, and in the final report was flagged as a critical area to be addressed (see Longfield 2002).

\section{Employment Equity in the 'Big Six' Banks}

The 'Big Six' banks are among the largest 12 employers covered by the Employment Equity Act, and are significant employers of both women 
and persons with disabilities (31 percent of persons with disabilities and about half of the women). Their significance as employers of members of the designated groups ( 78 percent of bank workers are members of the four designated groups, compared with 42 percent in the other sectors covered under the Act) makes them a good case study to examine how employment equity works on the ground. Other studies show that over time, employment gaps between designated groups and other employees closed faster in organisations with formalised and comprehensive employment equity programs than those without such programs (Leck, St. Onge and Lalancette 1995; Leck and Saunders 1996). My goal is to assess what progress the 'Big Six' have made towards employment equity for people with disabilities in the 15 years since legislation has required them to have formal employment equity programs. I address three central components of the Act described above, in the context of social exclusion and 'gendered organisations'. Specifically I investigate three questions. First, has the numerical representation of women and men with disabilities in the banks increased over time, and how does it compare with the labour market availability benchmark of 6.5 percent for persons with disabilities? Second, does the occupational distribution of women and men with disabilities reflect those of women and men without disabilities? Third, how have the banks addressed discriminatory barriers and exclusionary policies and practices that result from their employment systems, policies and practices?

I employed quantitative and qualitative methods to address these three questions (see England 2002). Human Resources Development Canada (HRDC) provided me with the detailed employment equity data for each of the banks covered (while publicly available, not all the data are published in the Annual Reports). I merged the data for the six banks because I am interested in them collectively as emblematic of 'Corporate Canada', rather than their relative individual performances. I look at the employment equity data from the first (1987) and most recent (2001) years they were collected. Although the employment equity data is collected for several occupational groupings, I aggregated the data to better capture the occupationally polarised structure of banking (managerial, professional and clerical occupations account for more than 90 percent of the jobs in Canadian banking ${ }^{7}$ ). There are drawbacks to these data. They do not allow me to determine what 'disability' people have, or the severity of the disability. I also cannot tell whether someone who identifies as a "person with a disability' had a disability when they were hired or became disabled once employed (increasingly common with an aging workforce) or choose to self-identify after they were hired.

My qualitative methods included a textual analysis of various documents relating to employment equity that I obtained from the six banks, the Canadian Bankers Association, and two archives associated with the banking industry. I also interviewed employment equity specialists at four of the 'Big Six' banks, as well as representatives of the Canadian Bankers Association. The purpose of my interviews was to get their assessment of the successes (and failures) of various aspects of their employment equity policies, especially in terms of their impact on women. I also asked questions about the hiring and retention of people with disabilities, and what sorts of jobs people with disabilities were in, and their efforts to address employment barriers faced by persons with disabilities.

The 'Big Six' banks employ significant numbers of women and persons with disabilities covered by the Act. The 2001 employment equity data indicate that they employed 31 percent of all the persons with disabilities workers in the federally regulated private sector covered by the Act (compared with 26 percent of those without disabilities). Also banking is highly feminised (71 percent of bank workers are women) compared to the overall employed labour force (47 percent of all workers are women); which helps explain why the banking sector employs about half of all women with and without disabilities covered by the Act. Because I am investigating banking, much of my attention focuses on Toronto, given its role as Canada's financial capital. The dominance of Toronto in Canadian banking employment is well established, the 'Big Six' are either headquartered in Toronto, or have a significant presence there (Coffey and

7 The 'other occupations' category include sales workers, services workers, crafts/trades workers and manual workers, some of which employed single digit numbers of people once divided by gender and disability. In 2001 the 'other occupations' only accounted for 264 bank workers across the whole of Canada (down from 1,162 jobs in 1987). 
Polèse 1999; Gad 1999). More generally, large urban centres are important for people with disabilities, who are heavily concentrated in cities, partially as an outcome of migration patterns for better and more social and rehabilitation services (Roeher Institute 1993). Urban-based people with disabilities are slightly more likely to be in paid employment than those living in rural area or small towns and cities (Roeher Institute 1993; Bunch and Crawford 1998). Reflecting these two points, in 200121.5 percent of all the persons with disabilities covered by the Employment Equity Act work in Toronto (the 2001 Census indicated that 16 percent of Canada's employed workforce is in Toronto), and the concentration is even higher for the 'Big Six' banks: one-third (35 percent) of their workers with disabilities are Toronto-based. ${ }^{8}$

Has the numerical representation of women and men with disabilities in the banks increased over time?

Table 1 shows the numerical representations for 1987 and 2001 for women and persons with disabilities employed by the 'Big Six' along with the relevant statistical benchmarks (for women they were 44.0 percent in 1987 and 46.4 percent in 2001; for persons with disabilities they were 5.4 percent in 1987 and 6.5 percent in 2001). I also include the representation by gender and disability status; however under the Act 'official' benchmarks are not required for these breakdowns. Table 1 shows the percents for Canada, Toronto, and 'The Rest of Canada' (which is the national data without Toronto) to get a glimpse of the sites of banking employment beyond the unusual case of Toronto which is dominated by the banks' headquarters. As Canada's financial capital, Toronto has a substantial share of the 'Big Six's' corporate occupations: 81 percent of all senior managers, 48 percent of middle and other managers ${ }^{9}$ and 53 percent of professionals employed by the 'Big Six'

8 I also analysed the data available for employment patterns beyond Toronto, I looked at the aggregate data for Canada minus Toronto, and the data available for eight large cities, particularly Montreal and Vancouver. While my primary focus is the patterns nationally and in Toronto, I occasionally make reference to my other analysis.

9 This is the occupational level associated with bank's regional managers and branch managers, occupations that tend to be more spatially dispersed relative to corporate functions. in Canada work in Toronto. By contrast only 30 percent of clerical workers are Toronto-based, because clerical work (and to a lesser extent, middle/other managers) are relatively more significant in back offices and bank branches than in corporate headquarters (Gad 1999). So, reflective of spatial divisions of labour in banking, 70 percent of clerical jobs are located outside Toronto.

First, in all three geographies, the numerical representation of women in the 'Big Six' is much higher than the benchmarks of 44.0 percent in 1987 and 46.4 percent in 2001 (banking is highly feminised relative to the other sectors covered by the Act). The percentage of women employed is lowest in Toronto and highest beyond Toronto, reflecting the more male-dominated corporate occupational structure of Toronto. The picture for persons with disabilities is very different. At all three scales, the percent of persons with disabilities employed by the 'Big Six' fell well below the benchmarks in both years. Geographically different patterns are associated with the first and most recent years of data. In 1987 there was little geographic variation in the percent of persons with disabilities employed by the 'Big Six' banks, 1.8 percent in Toronto and in 'The Rest of Canada'. In 2001 the statistical representation of persons with disabilities was a little higher in Toronto (1.8 percent) than for 'The Rest of Canada' (1.5 percent). However, the relative numerical representation of persons with disabilities basically remained the same over the 15 years (although there was actually a small absolute increase). But the labour force availability of persons with disabilities increased from 5.4 to 6.5 percent, and the banks were well below these benchmarks. HRDC calculates a 'representativity index' that compares the employer's percents with the benchmarks. In 1987 the 'Big Six's' representativity index was about onethird of the benchmark, but by 2001 it had dropped to about a quarter. This relative decline is especially alarming because in 1987, the banks had similar or slightly higher representativity indices than the other sectors covered by the Act, but in 2001 the banks' indices were slightly lower than in other sectors. In short, very little progress was made in the numerical representation of persons with disabilities working for the 'Big Six'.

I began my paper with a quote from Wendy Stienberg's evidence for the 2001 Parliamentary 
Table 1

Numerical representation of women and disabilities status in the 'Big Six' banks, 1987 and 2001

\begin{tabular}{|c|c|c|c|c|c|c|}
\hline Workers in the 'Big Six' (row in percents) & Women & $\begin{array}{l}\text { Persons } \\
\text { with } \\
\text { Disabilities }\end{array}$ & $\begin{array}{l}\text { Women } \\
\text { with } \\
\text { Disabilities }\end{array}$ & $\begin{array}{l}\text { Women } \\
\text { without } \\
\text { Disabilities }\end{array}$ & $\begin{array}{l}\text { Men with } \\
\text { Disabilities }\end{array}$ & $\begin{array}{l}\text { Men } \\
\text { without } \\
\text { Disabilities }\end{array}$ \\
\hline \multicolumn{7}{|l|}{1987} \\
\hline Benchmarks & 44.0 & 5.4 & & & & \\
\hline Canada & 76.9 & 1.9 & 1.3 & 75.6 & 0.6 & 22.5 \\
\hline Toronto & 68.0 & 1.8 & 1.2 & 66.8 & 0.8 & 31.2 \\
\hline 'The rest of Canada' (National data minus Toronto data) & 80.8 & 1.8 & 1.3 & 67.6 & 0.5 & 18.6 \\
\hline \multicolumn{7}{|l|}{2001} \\
\hline Benchmarks & 46.4 & 6.5 & & & & \\
\hline Canada & 71.6 & 1.7 & 1.4 & 70.2 & 0.7 & 27.7 \\
\hline Toronto & 61.2 & 1.8 & 1.0 & 60.2 & 0.9 & 37.9 \\
\hline 'The rest of Canada' (National data minus Toronto data) & 78.0 & 1.5 & 1.6 & 76.4 & 0.6 & 21.4 \\
\hline
\end{tabular}

NOTE: The benchmarks are based on the current labour force availability of the 'designated groups' in the general labour force as determined by the most recent Census (see text for further explanation). Benchmarks are available for women as a group and persons with disabilities as a group only. SOURCE: Employment Equity Act Report, 1988; HRDC 2002; unpublished HRDC data provided to the author

Review of the Act. She commented on the declining trend across all the sectors covered by the Act in the numerical representation of persons with disabilities. The downward trend began after 1995, when the representation of persons with disabilities reached a peak of 2.7 percent and has since declined. In banking there has also been a downward trend, but it began earlier in the decade and was closely associated with the recession of the early 1990s. The Act is intended to encourage employers to recruit more people from the designated groups, but the data do not draw a distinction between people who had a disability when they were hired versus those who became disabled once employed. As the work force ages, currently employed people may become disabled. Thus the 15 -year decline is also troublesome because the numerical representation includes people who already worked for the bank before identifying as persons with disabilities, and not only those new hires who have disabilities.

I discussed the numerical representation trends with the employment equity specialists at the 'Big Six' banks and with representatives at the Canadian Bankers' Association. I found it far easier to get them to talk about the trends and their policies around women than about persons with disabilities. In fact, in some of the interviews I found myself being manoeuvred away from disability issues towards discussions of their relative success around women (as a group) and visible minorities (see England 2002). So I rephrased my question, asking instead what aspect of their employment equity programs they were currently working hardest on. All answered persons with disabilities (one responded persons with disabilities and Aboriginals). For example:

Manager 3: Well [laughs] just like all the other financial institutions, we are probably focusing very much on the recruitment of people with disabilities.

Manager 1: We've actually launched an Employment Equity index where we've weighted the areas where we have the most work to do as an organisation. So that means strategically we're looking at people with disabilities and Aboriginal people.

I got a very clear sense that issues around persons with disabilities had been and continued to be a challenge for the employment equity managers. I was told repeatedly that recruiting and retaining persons with disabilities is difficult, and that it is not as simple as counting people and comparing that count to the 6.5 percent benchmark. For example, Manager 3 explained that:

Manager 3: Every year we do a gap analysis here (in Toronto) for the whole country and 
we look at our organisational goals (for employment equity) and then we at a corporate level, working with our businesses, sit down and figure out what those goals might look like and then get agreements from the different areas of the country as to what their numerical goals would be and then they tell us how they're going to accomplish it in the qualitative (employment system review) aspects of the planning.

The managers acknowledged that the banks have had poor performances regarding persons with disabilities and had various explanations as to why this was the case. The managers I interviewed spoke of devoting a lot of time and energy to initiatives focused on people with disabilities. All the managers lamented that seemingly despite their best efforts they employed a small number of people with disabilities. One manager told me:

Manager 2: Actually the banks have become concerned about their employment patterns of persons with disabilities and we're actually sponsoring research on-for financial institutions-on the recruitment of people with disabilities to sort of delve down and see whether or not there are actually disabled people out there who are attracted to the financial services sector and want to be employed by them. There's going to be a whole pile of research and information and then out of that we'll look at initiatives that we could work on to attract people with disabilities to the organisation.

The representative of the Canadian Bankers' Association confirmed that this was one aspect of their ongoing research. One of the other managers also suggested that 'banking might not suit people with disabilities'. These comments could be interpreted as suggesting that the problem of the low numerical representation lays with persons with disabilities themselves not wanting to work in banking rather than banking not being inviting enough for persons with disabilities (although perhaps the banks will address the findings once they became available). Other managers suggested that the 6.5 percent benchmark was too high, and most complained that the benchmark was out of date (it comes from the 1991 HALS), especially compared with the benchmarks for the other designated groups (all taken from the 1996 Census). It is likely, however, with the aging work force, that the 2001 PALS may actually produce a higher benchmark, meaning that the banks' representativity index could drop further. My analysis, then confirms Wendy Steinberg's comment that 'the track record for ensuring equity for persons with disabilities ... is far from shining' and persons with disabilities have experienced little progress under the Act in terms of numerical representation.

Does the occupational distribution of women and men with disabilities reflect those of women and men without disabilities?

The Act also obliges organisations to examine the occupational distribution of their employees through their annual audits and systems review. To explore the occupational distribution question (and whether the distribution has changed since1987), I use the index of dissimilarity, as well as inspecting the occupational profiles and net change in bank jobs by gender and disability status. In employment studies, the index of dissimilarity ${ }^{10}$ has long been a typical measure of occupational segregation (Duncan and Duncan 1955; Blau, Ferber and Winkler 1998; Fortin and Huberman 2002). The index of dissimilarity provides a method of measuring the degree of inequality in the mix of occupations, by comparing the distribution of one group relative to another. Low values indicate there is little difference in the mix of occupations (i.e. little segregation) and high values indicate highly segregated groups, because the two groups are distributed differently across the occupational profiles. Other research indicates that although occupation segregation still remains, the index of dissimilarity for gender has declined in recent decades (Reskin 1993; Blau, Ferber and Winkler

10 The index is calculated as follows:

$$
1 / 2 \Sigma_{\mathrm{i}}\left|\mathrm{M}_{\mathrm{i}-} \mathrm{F}_{\mathrm{i}}\right|
$$

where, $\mathrm{M}_{\mathrm{i}}$ is the percentage of men in the labour force employed in occupation $i$, and $F_{i}$ is the percentage of men in the labour force employed in occupation $i$. 
Table 2

Index of occupational dissimilarity for women and men with and without disabilities employed by the 'Big Six' banks, Canada and Toronto, 1987 and 2001

\begin{tabular}{|c|c|c|c|c|c|c|}
\hline \multirow[b]{2}{*}{ Canada } & \multicolumn{3}{|l|}{1987} & \multicolumn{3}{|l|}{2001} \\
\hline & $\begin{array}{l}\text { Women with } \\
\text { Disabilities }\end{array}$ & $\begin{array}{l}\text { Men with } \\
\text { Disabilities }\end{array}$ & $\begin{array}{l}\text { Women without } \\
\text { Disabilities }\end{array}$ & $\begin{array}{l}\text { Women with } \\
\text { Disabilities }\end{array}$ & $\begin{array}{l}\text { Men with } \\
\text { Disabilities }\end{array}$ & $\begin{array}{l}\text { Women without } \\
\text { Disabilities }\end{array}$ \\
\hline Men with disabilities & 56.6 & & & 39.5 & & \\
\hline Women without disabilities & 4.1 & 52.8 & & 4.5 & 38.3 & \\
\hline Men without disabilities & 63.8 & 8.5 & 45.5 & 39.6 & 3.8 & 38.4 \\
\hline
\end{tabular}

\begin{tabular}{|c|c|c|c|c|c|c|}
\hline \multirow[b]{2}{*}{ Toronto } & \multicolumn{3}{|l|}{1987} & \multicolumn{3}{|l|}{2001} \\
\hline & $\begin{array}{l}\text { Women with } \\
\text { Disabilities }\end{array}$ & $\begin{array}{l}\text { Men with } \\
\text { Disabilities }\end{array}$ & $\begin{array}{l}\text { Women without } \\
\text { Disabilities }\end{array}$ & $\begin{array}{l}\text { Women with } \\
\text { Disabilities }\end{array}$ & $\begin{array}{l}\text { Men with } \\
\text { Disabilities }\end{array}$ & $\begin{array}{l}\text { Women without } \\
\text { Disabilities }\end{array}$ \\
\hline Men with disabilities & 49.3 & & & 28.1 & & \\
\hline Women without disabilities & 6.9 & 43.8 & & 5.2 & 29.8 & \\
\hline Men without disabilities & 55.6 & 9.6 & 49.9 & 28.9 & 4.4 & 30.3 \\
\hline
\end{tabular}

SOURCE: unpublished HRDC data provided to the author

1998; Fortin and Huberman 2002). I calculated separate indices for four groups of workers by disability status and gender for Canada and Toronto for 1987 and 2001, and the results are in Table 2 .

The calculations for Toronto show a drop in magnitude of the dissimilarity index over time for each group with every other group. This was also the trend nationally, except for a slight increase for women with disabilities and women without disabilities (largely due to the cumulative effect of gaps between several occupations rather than women with disabilities being heavily concentrated in one occupation compared with women without disabilities). In all instances, both nationally and in Toronto, there is less occupational segregation in the within-gender groups (in the single digit range), and this echoes the findings of other studies using the index of dissimilarity (for example, Fortin and Huberman 2002). And in all cases (except Toronto in 2001) the highest index is between women with disabilities and men without disabilities. But this combination also saw the most notable decline in the index of dissimilarity over the 15-year period, indicating a crucial decrease in occupational segregation between the least and most privileged people in the gender/ disabilities nexus. Another way to interpret the index is that it indicates what percentage of one group would need to change occupations to achieve equality across occupations. So in Canada in 1987,64 percent of women with disabilities or men without disabilities would have needed to change jobs to achieve occupational parity, whereas in 2001 only 40 percent would have needed to do so. Comparing the national and Toronto scales, the indices for both years are slightly lower overall in Toronto than they were nationally, and over the 15 years the gaps closed more in Toronto than nationally, especially for women with disabilities. And the difference between the most and least segregated combinations is also much less in Toronto than nationally (for example in 2001 the range in Toronto is from 30.3 to 4.4 , compared with 39.6 and 3.8 for Canada). The overall trend then, is towards a decline in occupational segregation over time, especially in Toronto, and that the gap is closing between women with disabilities and the other three groups of workers (women without disabilities, men with disabilities and men without disabilities).

Some of the explanation for the differences between the index of dissimilarity for Toronto versus Canada is because, as Canada's financial capital, Toronto has a substantial share of the 'Big Six's' 
Table 3

Occupational distributions in the 'Big Six' banks, women and men with and without disabilities, Canada and Toronto, 1987 and 2001

\begin{tabular}{|c|c|c|c|c|c|c|c|c|c|c|}
\hline & \multicolumn{5}{|l|}{1987} & \multicolumn{5}{|l|}{2001} \\
\hline & $\begin{array}{l}\text { Total } \\
\text { Labour } \\
\text { Force }\end{array}$ & $\begin{array}{l}\text { Women } \\
\text { with } \\
\text { Disabilities }\end{array}$ & $\begin{array}{l}\text { Women } \\
\text { without } \\
\text { Disabilities }\end{array}$ & $\begin{array}{l}\text { Men } \\
\text { with } \\
\text { s Disabilities }\end{array}$ & $\begin{array}{l}\text { Men } \\
\text { without } \\
\text { Disabilities }\end{array}$ & $\begin{array}{l}\text { Total } \\
\text { Labour } \\
\text { Force }\end{array}$ & $\begin{array}{l}\text { Women } \\
\text { with } \\
\text { Disabilities }\end{array}$ & $\begin{array}{l}\text { Women } \\
\text { without } \\
\text { Disabilities }\end{array}$ & $\begin{array}{l}\text { Men } \\
\text { with } \\
\text { Disabilities }\end{array}$ & $\begin{array}{l}\text { Men } \\
\text { without } \\
\text { Disabilities }\end{array}$ \\
\hline \multicolumn{11}{|l|}{ Canada } \\
\hline Senior managers & 0.6 & - & 0.0 & 2.5 & 2.7 & 0.7 & 0.2 & 0.3 & 2.1 & 1.9 \\
\hline Middle and other managers & 20.5 & 7.8 & 10.7 & 48.2 & 53.7 & 17.3 & 11.3 & 12.1 & 31.6 & 30.3 \\
\hline Professionals & 10.7 & 6.6 & 7.9 & 17.7 & 20.4 & 20.4 & 14.8 & 15.2 & 31.0 & 33.4 \\
\hline Supervisors & 5.4 & 6.9 & 6.2 & 3.9 & 2.5 & 5.4 & 4.5 & 6.2 & 2.1 & 3.6 \\
\hline Clerical personnel & 62.0 & 78.0 & 75.0 & 24.7 & 18.6 & 56.1 & 69.1 & 66.2 & 32.1 & 30.5 \\
\hline Other occupations & 0.7 & 0.6 & 0.3 & 3.0 & 2.2 & 0.1 & 0.0 & 0.1 & 1.1 & 0.3 \\
\hline \multicolumn{11}{|l|}{ Toronto } \\
\hline Senior managers & 1.4 & - & 0.1 & 4.9 & 4.4 & 1.5 & 0.4 & 0.7 & 2.3 & 2.9 \\
\hline Middle and other managers & 23.0 & 8.7 & 14.1 & 35.4 & 42.3 & 21.8 & 16.4 & 17.3 & 26.8 & 28.9 \\
\hline Professionals & 14.7 & 8.5 & 9.8 & 23.2 & 25.0 & 28.4 & 24.4 & 22.1 & 39.2 & 38.3 \\
\hline Supervisors & 5.5 & 8.8 & 6.9 & 4.1 & 2.6 & 5.5 & 4.0 & 6.7 & 2.3 & 3.8 \\
\hline Clerical personnel & 54.0 & 72.0 & 68.5 & 28.1 & 23.0 & 42.5 & 53.7 & 53.1 & 27.9 & 25.7 \\
\hline Other occupations & 1.3 & 2.1 & 0.6 & 4.3 & 2.7 & 0.3 & 0.1 & 0.2 & 1.6 & 0.4 \\
\hline
\end{tabular}

SOURCE: unpublished HRDC data provided to the author

corporate occupations (for example, 81 percent of all senior managers, and 53 percent of professionals employed by the 'Big Six' in Canada work in Toronto). This spatial division of labour is evident in Table 3, which shows the occupational distributions of the 'Big Six' banks in Toronto and Canada for 1987 and 2001. In 1987 nationally, and to a lesser extent in Toronto, both women with and without disabilities were heavily concentrated in the 'pink-collar ghetto' of clerical work (around 75 percent nationally and 70 percent in Toronto). The largest group of men, both with and without disabilities, were concentrated in middle management; beyond that men with disabilities were more likely to be in clerical work than men without disabilities (whose second occupational cluster was professional occupations). These data indicate the persistence of gendered occupational segmentation; women tend to be ghettoised into a smaller array of occupations relative to men. When the two largest occupational clusters of each group of men are added together (73 percent of men with disabilities are in middle management or clerical occupations; and 74 percent of men without disabilities are in middle management or professional occupations) the number is still less than the percent of women in clerical work alone. So basically in 2001 , the pattern of gendered occupational segregation is still evident, but it was much less stark than in the past.

In both years, Toronto has lower indices of dissimilarity relative to Canada as a whole because all four groups of workers are more evenly distributed across occupations than they are nationally. For instance, nationally in 2001, a little over a quarter of women with and without disabilities were in managerial and professional occupations, whereas in Toronto the proportions are higher: 41.2 percent of women with disabilities, and 40.1 percent of those without. $^{11}$ Between 1987 and 2001, women made impressive inroads into higher status jobs in Toronto. The spatial concentration in Toronto suggests that women (with and without disabilities) have more opportunities to reach positions of authority and autonomy with decision-making power in Toronto, relative to the rest of the country. That said there is still a significant clustering of women in the typical job for women in banking: clerical work. And the cluster is larger for women with disabilities (although this is less

11 When I created the occupational distributions for Canada without the Toronto data, the proportion of women employed in high status occupations dropped to around 20 percent. 
evident in Toronto than nationally). By 2001, women's occupational segregation is less pronounced in banking at both the national and Toronto scales, suggesting some achievement of equity in terms of occupational distribution. And although the pink-collar ghetto for women persists, there appears to be some success in policies to move more women, including women with disabilities, into higher status jobs with autonomy and authority.

The decline in occupational segregation is also because of changes in men's employment patterns. Between 1987 and 2001, both nationally and in Toronto, men (with and without disabilities) became less concentrated in senior and middle management, while their statistical representation in professional occupations increased. There were also changes in clerical work. Nationally the proportion of men in clerical work increased, but in Toronto they remained about the same in both years. The 15-year period I am addressing in this paper, was an era of significant restructuring in Canadian banking. There was a loss of clerical jobs in the mid 1990s and the recession of the early 1990s saw a decline in the total number of persons with disabilities employed relative to the rest of the banks' employees. I asked the managers about these trends. One manager admitted:
Manager 4a: Years ago we would just sort of say we'd be happy with just recruiting someone in with a disability and they would come into a call centre and that centre might be one that had a high turnover or redundancy risk, because of technology or automation. So we weren't making an investment that was productive for us and certainly not for the individual.... But you know, we suffered the hard way for a number of years when we were consolidating centres that were highly administrative and they were also easily adapted for people with certain types of disabilities. The risk of that was a shortterm investment, a bad investment.

While the economy improved in the late 1990s, the job recovery for persons with disabilities, especially women has been much slower than for those without disabilities (once again reflective of Wendy Steinberg's remarks about a declining trend in the employment of persons with disabilities, and their limited progress under the Act). These patterns are also seen in banking. Table 4 shows the net percent change in jobs between 1987 and

Table 4

Change in occupations in the 'Big Six' banks, women and men with and without disabilities, Canada and Toronto, 1987 to 2001

\begin{tabular}{|c|c|c|c|c|c|}
\hline & \multicolumn{5}{|c|}{ Percent Change } \\
\hline & $\begin{array}{l}\text { Total Labour } \\
\text { Force }\end{array}$ & $\begin{array}{l}\text { Women with } \\
\text { Disabilities }\end{array}$ & $\begin{array}{l}\text { Women without } \\
\text { Disabilities }\end{array}$ & $\begin{array}{l}\text { Men with } \\
\text { Disabilities }\end{array}$ & $\begin{array}{l}\text { Men without } \\
\text { Disabilities }\end{array}$ \\
\hline \multicolumn{6}{|l|}{ Canada } \\
\hline Total & 10.9 & 19.0 & 4.9 & 32.2 & 40.1 \\
\hline Senior managers & 28.8 & na & $1,280.0$ & 8.7 & $(0.9)$ \\
\hline Middle and other managers & $(6.7)$ & 72.2 & 18.7 & $(13.3)$ & $(20.8)$ \\
\hline Professionals & 110.6 & 165.7 & 102.2 & 131.9 & 129.9 \\
\hline Supervisors & 12.0 & $(22.1)$ & 4.4 & $(28.6)$ & 95.8 \\
\hline Clerical personnel & 0.3 & 5.5 & $(7.3)$ & 71.7 & 129.7 \\
\hline \multicolumn{6}{|l|}{ Toronto } \\
\hline Total & 38.8 & 17.8 & 25.2 & 55.1 & 68.3 \\
\hline Senior managers & 48.5 & na & $1,156.5$ & $(27.8)$ & 11.6 \\
\hline Middle and other managers & 31.3 & 124.0 & 53.1 & 17.6 & 15.2 \\
\hline Professionals & 169.0 & 238.8 & 182.1 & 161.6 & 157.4 \\
\hline Supervisors & 38.2 & $(47.1)$ & 21.8 & $(13.3)$ & 143.3 \\
\hline Clerical personnel & 9.2 & $(12.0)$ & $(3.0)$ & 53.8 & 88.1 \\
\hline
\end{tabular}

SOURCE: unpublished HRDC data provided to the author 
2001 overall and for each of the four groups of workers by gender and disability status (I excluded 'other occupations' from the table because they account for a relatively small number of people. There were net losses for each of the four groups of workers. Several points are noteworthy about this table. First, nationally there was a small overall increase (11 percent) in the number of bank workers, whereas Toronto saw much higher growth (39 percent). Second, men overall saw far higher net increases in jobs than did women, particularly in Toronto. Third, looking at the changes in terms of the occupations of each group reveals important patterns. I will deal with the national picture first. There was an impressive increase in women employed in middle management and professional occupations (there have also been some gains at the senior managerial level, but as Table 3 showed there is still a noticeable 'glass ceiling' effect at play). These gains have been especially important for women with disabilities. For instance, although Table 3 shows that in 2001 the actual percent of women without disabilities is larger than for those with disabilities, Table 4 indicates that the rate of change over time for women with disabilities is greater. Thus women with disabilities experienced greater improvement in their proportional representation in middle management and professional occupations, meaning they saw increased opportunities for jobs with decision-making power and movement towards a critical mass that could effect further organisational change (as did women without disabilities).

Nationally there was miniscule growth of 0.3 percent in clerical work between 1987 and 2001 (a net gain of a mere 281 clerical jobs). This actually reflects a recovery from massive job loss in the early to mid-1990s. However, there are important differences by gender and disability status: there was a net loss of 6,540 (7.3 percent) jobs for women without disabilities, and a slight net increase (5.5 percent) for women with disabilities in clerical work. On the other hand there was an enormous increase for men, notably men without disabilities (who saw a net gain of 130 percent or 8,628 clerical jobs!). Relatively speaking then, there are now more men in clerical work than in the past. Nationally there were declines in both middle management and the category 'other occupations' (jobs such as cleaning and food services are increasingly contracted out and those people are often not included in the employment equity data). The restructuring of the banking industry since the late 1980s involved a decline in middle management jobs, and here most affected were men, especially those without disabilities (their 20.8 percent loss nationally represents 3,998 jobs).

Some similar, but also different patterns emerged in Toronto between 1987 and 2001. First, the net growth of 'Big Six' employment was more substantially in Toronto than it was nationally. Second, as at the national level, notable increases are seen in senior management and professional occupations, especially for both groups of women (suggesting that Toronto offers significant opportunities for women to obtain high status jobs in banking). Third, Toronto saw a larger increase in clerical work than the national scale, but this translates into far greater losses for women with disabilities and substantial increases for men, although less than was seen nationally. Finally, a closer look at the net job percent decreases by disability status reveals disconcerting patterns in Toronto. Persons with disabilities suffered most of the net job losses: specifically women with disabilities saw declines in clerical work, men with disabilities lost senior management jobs, and both women and men with disabilities lost supervisory positions. Whereas at the national level each of the four groups of workers experienced net job losses, in Toronto most job losses were among persons with disabilities, and the only other net loss was for women without disabilities in clerical work, but this was the smallest net loss ( 3 percent) of all. In fact over this 15 -year period in Toronto, persons with disabilities represented a 4.2 percent share of the net job loss, but only 1.6 percent of the net increase in jobs.

On the whole, my findings about occupational change are more encouraging than those of the overall trend in the numerical representation of persons with disabilities, so while there has been little improvement in the numerical representation of persons with disabilities, there have been some positive shifts in terms of occupations of those employed by the 'Big Six' (of course, some of the improvement could be because people already employed in higher status jobs become disabled). Also by considering the patterns nationally and for Toronto, it becomes clear that the sorting out of the 'Big Six' workers is more complicated and contradictory than the overall national data suggest. 
Nationally, people without disabilities were disproportionably affected by job losses (women in clerical occupations and men in middle management), so nationally the net losses were gendered, but in Toronto persons with disabilities were most affected. So, although Toronto has a larger proportion of workers with disabilities relative to 'The rest of Canada' (Table 1), the more progressive workplace equity there is soured by the disproportionate job losses experienced by persons with disabilities since 1987.

How have the banks addressed discriminatory barriers and exclusionary policies and practices?

The third component of the Act addresses exclusionary policies and practices, but the Act does not really explicitly address creating an accommodating workplace climate (a point I will return to later). Instead, the primary policy lever and ultimately the primary measure of success for the Act is the numbers gathered through the 'workforce survey' (Agocs 2002; Kobayashi 2002). Of course it is common for social policies to focus on quantifiable and measurable performance targets. However, social justice is at least as much about the quality of social relationships as it is about statistical effects (Young 1990; Fraser 1997). The 'gendered organization' literature posits that workplace climate and everyday informal social relations are pivotal in shaping social relations in organisations. And, I would argue, theorising the banks as gendered organisations provides an important perspective in terms of effecting meaningful organisational change. Reaching workplace equity involves the creation of a workplace climate where the four designated groups experience supportive and responsive supervision, along with a sense of being respected and valued. An accommodating workplace is one that does not perpetuate patterns of systemic discrimination, includes supportive supervisors, skills improvement training and professional development; and where workers receive encouraging performance appraisals, and opportunities for some involvement in decision-making power (Bakan and Kobayashi 2000; Agocs 2002).

I talked with the employment equity managers about what sorts of trends they had noted in their practices and policies around persons with disabilities, and how they had changed over time. One of the sets of interviews I conducted at Bank 4 was with two employment equity managers. One of these two managers had recently been hired specifically to focus on persons with disabilities and aboriginals (they claimed that they were unique among the 'Big Six' in having this sort of dedicated human resource management line). We had the following exchange:

Manager 4a: We're creating real opportunities with futures rather than just meeting our own sort of needs and numbers.... We've kind of matured and we're at a point now where we're saying we need to identify jobs that are going to have a true sort of longevity. And you can certainly walk around the organisation and see people with disabilities, so there's no question that it's successful.

$K E$ : So you're trying to get them out of straight sort of entry-level jobs?

Manager 4a: Yes, we're trying to target roles that have a lot more of depth and growth in them so that we're not creating a limitation from day one. But it's not easy.

Manager 4b: And the positions we've brought people into just recently are geared to a higher level, they're not entrylevel positions. But we've had to go out to find those people; we've had to make a more concerted effort because we want to bring them into a more significant opportunity long term for us. It's hard, but we're getting better at it.

Notice two things about this exchange. Manager $4 \mathrm{~b}$ is careful to add nuance to Manager 4a's comments. Manager $4 \mathrm{~b}$ is the manager who holds the disabilities and Aboriginal issues portfolio. Manager $4 \mathrm{a}$ here and elsewhere in the interview was much more likely to concentrate on numbers, whereas Manager $4 \mathrm{~b}$ was more likely to address issues about social inclusion and the chilly corporate climate. Both managers describe recruiting, hiring and retaining persons with disabilities as 'not easy' and 'hard', but still seemed pleased with their progress and efforts. Of course I am very aware 
that the managers were choosing their words carefully (as was I), and that it is likely they wanted to project the right sort of image of themselves as managers and their banks as exemplary practitioners of employment equity. I do not intend to be dismissive of the managers' remarks. These and the other managers were clearly appreciative of the banks poor performance regarding people with disabilities. Manager 3 told me:

We're focusing very much on the recruitment of people with disabilities and we have some specific initiatives attached to them because we find we have to. It's just not going on campus and finding those individuals. So we've created programs and initiatives and some recruitment strategies around focusing on getting those people in.

My textual analysis and the interviews indicate that the banks have already introduced various 'initiatives' aimed at improving their numerical representation of people with disabilities and the workplace climate for them once employed. Almost all the documents stated that the goal of their initiatives is to transform the banks into more disability-friendly workplaces as well as to increase the recruitment and retention of people with disabilities. On the whole these initiatives have been introduced since about the mid-1990s. Here I will give only a sample of some of them. A couple of the banks have created advising committees that basically draw on persons with disabilities as experts of their own experience. For instance, the Bank of Montreal 'Workplace Equality Advisory Councils' and 'Affinity Groups' meet monthly to provide feedback and suggestions about workplace equity. The Toronto-Dominion Bank has an extensive mentoring program (which includes partnership between people not in the same location through their 'virtual mentoring' program). Other banks are drawing on the expertise of disability activists outside the bank. CIBC formed a partnership with Disabled People for Employment Equity and Human Rights (DPEEHRG) $^{12}$ in 2001 to help the bank increase its

12 DPEEHRG is a coalition of organisations, including the Canadian Mental Health Association, Ontario Division, the Canadian Hearing Society, the March of Dimes, Epilepsy Ontario, the Ontario Association for Community Living and the Ontario Association for the Deaf. They work together to improve employment opportunities for persons with disabilities. ability to hire and retain persons with disabilities. Other initiatives can be seen as efforts to increase and enrich the future pool of potential employees. A number of the banks have scholarships and apprenticeships for high school and university students with disabilities, and some have formed partnerships with community groups to help train people with disabilities. For many years, the Toronto-Dominion Bank has had an annual open day called 'Access-Ability Day' to showcase the ways the bank is accessible to both workers and customers.

Previous research indicates that the attitudes of the manager or employer of a person with disabilities are critical for a positive work experience. All banks require in-house awareness and sensitivity training for managers and supervisors. For instance, Scotiabank developed a video and discussion guide called 'Valuing People...Valuing Diversity' aimed at managers and unit heads to 'create a higher level of sensitivity to diversity issues through open discussion to develop strategies for improvement in (their) branch or office'. To address manager misperceptions about the costs of accommodation, the Royal Bank recently introduced a program that allows managers and employees to spend up to $\$ 3,000$ per person on workplace assessments and to make purchases to accommodate a worker's disabilities. However, critics (including workers with disabilities) raise concerns that the initiatives have yet to effectively shift organisational cultural practices and politics. Manager 3 explained to me that their bank has responded to such concerns by considering 'clear evidence of accountability' as part of the annual reviews of managers (one other manager commented on a possible move in that direction at their bank).

$K E$ : It sounds like that over time employment equity planning has become tied to the managers' performance reviews. Is that right?

Manager 3: It's been evolutionary for sure and the work keeps getting better. Their plans, their numerical goals and their qualitative plan to accomplish them. There was an accountability around the plans, but we also didn't hold anybody's feet to the fire if they weren't accomplishing what 
they said. So yes, since (they introduced accountability as part of performance review) we've had an impact because of some of those things. And it's just been building on and trying to enhance the accountability processes that are there.

I am mindful that my interviews were with employment equity managers who, presumably, are committed to workplace equity. Effecting material and, especially attitudinal, change beyond their offices is another matter, especially in terms of everyday practices (including those of executives, managers and co-workers) that cumulatively and recursively construct certain people as 'disabled' and 'out of place' in the banks. Ableism is normative and often reproduced unconsciously in ways that normalise what can be disabling social barriers and the social exclusion of persons with disabilities. Recent interventions by feminist scholars point to the importance of addressing gendered organisations and gendered and embodied work practices. So, although the Employment Equity Act addresses exclusionary formal policies and practices, the Act does not adequately address informal workplace practices. Workplace culture is not monitored through the compliance review process, and there is still very little published that investigates the implications of workplace culture for employment equity policy (Agocs 2002). Indeed, Agocs (2002) argues that a critical weakness of the Act is the lack of provision to address systemic discrimination in the workplace. The Abella Report (1984) did recommend measuring the numerical progress of the designated groups, and this became the cornerstone of the Act. However, Abella's recommendations also included providing training opportunities, publicly funded child care, and creating an accommodating workplace climate, and these recommendations are not really addressed by the Act. Of course, these are critical in the development of truly equitable workplaces and for transforming workplaces dominated by white, able-bodied men (Poole and Rebick 1993; Bakan and Kobayashi 2000; Agocs 2002).

\section{Conclusion}

After 15 years of employment equity legislation, the 'Big Six' banks have only achieved limited success in workplace equity for persons with disabilities. The numerical representation of people with disabilities in Toronto is the same in 2001 as it was in 1987, and there was a decline at the national scale. At less than 2 percent of the banks' workforce, it falls far below the 6.5 percent benchmark based on the 1991 HALS. For different sorts of reasons this statistical under-representation deeply concerns HRDC, disability activists and the banks; especially as for some years the banks were actually improving their relative number of persons with disabilities. Obviously these numbers are 'far from shining' as Wendy Steinberg puts it. On the other hand, the occupational clustering data indicate more positive numerical progress, so the decline in occupational segregation since the enactment of Employment Equity is cause for some celebration. There has been a notable increase in the numbers of women in management and professional occupations, and the increase for women with disabilities is especially encouraging. Women with disabilities (and women without disabilities) are less concentrated in the 'pink-collar' ghetto than in the past, although it is still the job that a woman with disabilities is most likely to have in banking. My findings suggest that employment equity has had a differential effect, certain groups of women and people with disabilities have greatly benefited from the banks' equity policies, while others have benefited much less, if at all. Indeed it is entirely possible that some of the increase in women with disabilities into decision-making roles was partly because of women becoming disabled once already employed (especially because the rate of disability does increase with age). In a similarly sceptical vein, Carol Agocs (2002) contends that, given the Act's reliance on numerical representation, some of the 'improvements' have actually been achieved because the downsizing of middle management and early retirement packages resulted in the decrease in numbers of white men without disabilities. Certainly my analysis suggests this may well also be the case for banking, given the decline in middle management at least at the national level. Similarly some of the 'improvements' might be because disabilities increase with age, and as a bank's workforce ages, the proportion of workers with disabilities increases, bolstering overall numerical representation of persons with disabilities without substantial numbers of new hires. 
Because the 'Big Six' are so evident in Canada's economic landscape, their performances as employers of the employment equity designated groups are closely scrutinised. Their significance as employers of members of the designated groups (78 percent of bank workers are members of the designated groups, compared with 42 percent in the other sectors covered under the Act) means their employment equity practices and policies have the potential to have a significant impact not only on their employees, but also on how employment equity is perceived and understood by other private sector businesses (including those not covered by the legislation) and the general public. The 'Big Six' are in a strong position to lead by example, to provide 'best practices', and create innovative management training around employment equity. These could have important spill-over effects, this is especially important with the cutbacks in the public sector (supposedly the exemplary practitioners of employment equity) and because of the current backlash against both federal and provincial employment equity legislation and policies (Bakan and Kobayashi 2000). Evidence shows that organisations with formalised and comprehensive employment equity programs closed the gaps between designated groups and other employees faster than those without such programs (Leck, St. Onge and Lalancette 1995; Leck and Saunders 1996).

Addressing social relations and everyday practices are as important as tracking the statistical outcomes of employment equity. As Kobayashi (2002, 245) argues, despite "what appear to be excellent legislation, policy and official practices' employment equity has not been more successful because 'in most workplaces there has not yet been sufficient development of the mutually reinforcing elements of numbers and cultural change' (emphasis added). Like many others, I want to see the Act improved and strengthened, and to have legislation more common at the provincial/territorial scale which, after all, covers the vast majority of workers in Canada (Bakan and Kobayashi 2000; England and Gad 2003). As a partial product of people with disabilities demanding social justice, I see employment equity as part of a broader network of change, which includes better coordination of disability-related supports, income support programs and other programs/policies and improving the access of people with disabil- ities to education and training to increase their employment opportunities (Fawcett 2000; HRDC 2000). Disability studies promote a vision of people with disabilities as independent, full citizens rather than medicalised, dependent objects of pity. The civil rights flavour of this approach places responsibility for the plight of people with disabilities on broad social mechanisms that operate to exclude people with disabilities. All segments of society are complicit in perpetuating the exclusion of people with disabilities, and thus share responsibility for reaching the goal of inclusion. Change requires dismantling ableist barriers and confronting ableism, whether in the workplace or elsewhere, so that, in the words of Waddington and Diller $(2000,2)$ 'prejudice may abate and the necessity for legal intervention may diminish'.

\section{References}

AAltio, I., and mills, A.J. 2002 Gender, Identity and the Culture of Organizations (London: Routledge)

ABElla, R.S. 1984 Equality in Employment: A Royal Commission Report (Ottawa: Minister of Supplies and Services Canada)

ACKER, J. 1990 'Hierarchies, jobs, and bodies: A theory of gendered organizations' Gender and Society 4(2), 139-158

—. 2000 'Revisiting class: thinking from gender, race and organization' Social Politics 7(2), 192-214

AGocs, c. 2002 'Canada's employment equity legislation and policy, 1987-2000: the gap between policy and practice' International Journal of Manpower 23(3), 256-276

ARMSTRONG, P. 1997 'The state and pay equity: juggling similarity and difference, meaning and structures' in Women and the Canadian Welfare State: Challenges and Change, eds P.M. Evans and G.R. Wekerle (Toronto: University of Toronto Press) 246-265

BAKAN, A.в., and Kobayashi, A. 2000 Employment Equity Policy in Canada: An Interprovincial Comparison (Ottawa: Status of Women in Canada)

BARnes, M., HeAdy, C., midDleton, s., and millar, J. 2003 Poverty and Social Exclusion in Europe (London: Routledge)

BERTRAM, R., and SHOBROOK, s. 1998 'You have to be twice as good to be equal: placing women in Plymouth's Davenport Dockyard' Area 30(1), 59-65

BLAU, F.D., FERBER, M.A., and WINKLER, A.E. 2002 The Economics of Women. Men and Work, 4th edition (Upper Saddle River, NJ: PrenticeHall)

BOYER, K. 1998 'Place and the politics of virtue: clerical work, corporate anxiety, and changing meanings of public womanhood in early 20th century Montreal' Gender, Place and Culture 5(3), 261-276

BRITTON, J.N.H. 1996 ed. Canada and the Global Economy (Montreal: McGill-Queen's University Press)

BUNCH, M., and CRAWFORD, C. 1998 Persons with Disabilities: Literature Review of the Factors Affecting Employment and Labour Force Transitions (Hull: Applied Research Branch, HRDC)

BURGESS, B. 2000 'Foreign direct investment: Facts and perceptions about Canada' The Canadian Geographer 44(2), 98-113 
BUTLER, R., and BOWLBY, S. 1997 'Bodies and spaces: An exploration of disabled people's experience of public space' Environment and Planning D: Society and Space 15, 411-433

CANADIAN COUNCIL ON SOCIAL DEVELPOMENT. 2002 Disability Information Sheet (Numbers 2, 4, 5, 8) (downloaded from http://www.ccsd. $\mathrm{ca} /$ drip, February 2003)

CHOUINARD, v. 1999 'Body politics: Disabled women's activism in Canada and beyond' in Mind and Body Spaces: Geographies of Illness, Impairment and Disability, eds R. Butler and H. Parr (London and New York: Routledge) 142-156

_. 2001 'Legal peripheries: Struggles over disabled Canadians places in law, society and space' The Canadian Geographer 45(1), 187-192

COFFEY, W.J., and POLĖSE, M. 1999 'A distinct metropolis for a distinct society? The economic restructuring of Montreal in the Canadian context' Canadian Journal of Regional Science 22(1/2), 23-40

COLELLA, A. 2001 'Coworker distributive fairness judgments of the workplace accommodation of employees with disabilities' Academy of management Review 26(1), 100-116

CONSULTATION GROUP ON EMPLOYMENT EQUITY FOR WOMEN. 1995 Looking to the Future: Challenging the Cultural and Attitudinal Barriers to Women in the Public Service (Ottawa: Treasury Board of Canada Secretariat) available online at: http://www.tbs-sct.gc.ca/ pubs_pol/hrpubs/TB_852/LFTOC_e.html, downloaded May 2002

D'AUBIN, A. 1987 'Disabled women's issues: a COPOH discussion paper' (Winnipeg: Coalition of Provincial Organizations of the Handicapped)

DAWNCANADA. 2001 'Our history' available online at: http:// www.dawncanada.net/history.htm, downloaded June 2001

DAWNONTARIO. 1990 'Obstacles to equality: the double discrimination of women with disabilities overview article' by Rannveig Traustadottir, available online at: http://dawn.thot.net/pub.html, downloaded June 2001

_. 2002 DisAbled Women's Network Ontario 'Home Page', available online at: http://dawn.thot.net/index.html, downloaded January 2002

DRIEDGER, D. 1989 The Last Civil Rights Movement (London: Palgrave Macmillan)

DUNCAN, O.D., and DUNCAN, B. 1955 'A methodological analysis of segregation indices' American Sociological Review 20, 210-217

DYCK, I. 1999 'Body troubles: women, the workplace and negotiations of a disabled identity' in Mind and Body Spaces: Geographies of Illness, Impairment and Disability, eds R. Butler and H. Parr (London and New York: Routledge), 119-137

EMPLOYMENT AND IMmigRATION CANADA. 1988 Employment Equity Act: Annual Report to Parliament 1988 (Ottawa: Supply and Services Canada)

ENGLAND, K. 2002 'Interviewing elites: cautionary tales about researching women managers in Canada's banking industry' in Feminist Geography in Practice: Research and Methods, ed P. Moss (Oxford: Blackwell), 200-213

ENGLAND, K., and GAD, G. 2003 'Social policy at work? Equality and equity in women's paid employment in Canada' Geojournal (in press)

FAWCETT, G. 1996 Living with Disability in Canada: An Economic Portrait (Hull: Canadian Council on Social Development, sponsored by HRDC)

-. 2000 Bringing Down the Barriers: The Labour Market and Women with Disabilities in Ontario (Ottawa: Canadian Council on Social Development)

FOUGEYROLLAS, P., NOREAU, L., and ST-MiChEL, G. 1997 'The measure of the quality of environment' ICIDH and Environmental Factors International Network 9, 32-39
FORTIN, N.M., and HUBERMAN, M. 2002 'Occupational gender segregation and women's wages in Canada: an historical account' Canadian Public Policy 28 supplement, S1 1-S39

FRASER, N. 1997 Justice Interruptus: Critical Reflections on the 'Postsocialist' Condition (London and New York: Routledge)

GAD, G. 1999 'Downtown Montreal and Toronto: distinct places with much in common' Canadian Journal of Regional Science 22 $(1 / 2), 143-170$

GLEESON, B. 1999 Geographies of Disabilities (London and New York: Routledge)

GORDON, D. 2000 Poverty and Social Exclusion in Britain (York: John Rowntree Foundation)

halford, S., SAVAGE, M., and witz, A. 1997 Gender, Careers and Organizations (Basingstoke: Macmillan)

HALL, E. 1999 'Workspace: Refiguring the disability-employment debate' in Mind and Body Spaces: Geographies of Illness, Impairment and Disability, eds R. Butler and H. Parr (London and New York: Routledge) 138-154

HILlS, J., BURCHARDT, T., and PIACHAUD, D. 2002 Understanding Social Exclusion (Oxford: Oxford University Press)

HINE, J., and MITCheLL, F. 2001 'Better for everyone? Travel experiences and transport exclusion' Urban Studies 38(2), 319-332

humAn ResourCes DEVElopMent CANADA (HRDC). 2000 In Unison 2000: People with Disabilities in Canada (Federal/Provincial/Territorial Ministers Responsible for Social Services). available online at: http://socialunion.gc.ca/In_Unison2000/iu3200e.html, downloaded February 2003

—. 2002. Annual Report: Employment Equity Act 2002 (Ottawa: Minister of Public Works and Government Services Canada)

IMRIE, R. 1996 Disability and the City: International Perspectives (London: Paul Chapman Publishing)

JAIN, H.C., and VERMA, A. 1996 'Managing workforce diversity for competitiveness: the Canadian experience' International Journal of Manpower 17(4/5), 14-29

JONGBLOED, L. 1996 'Factors influencing the employment status of women with multiple sclerosis' Canadian Journal of Rehabilitation 9(4), 213-222

-. 2003 'Disability policy in Canada: an overview' Journal of Disability Policy Studies 13(4), 203-209

KANTER, R.M. 1977 Men and Women of the Corporation (New York: Basic Books)

KERZNER, L., and BAKER, D. 1999 'A Canadians with disabilities act?' available online at: http://www.pcs.mb.ca/ ccd/cda.html, downloaded June 2001

KITCHIN, R. 1998 “"Out of place”, "Knowing one’s place”: space, power and the exclusion of disabled people' Disability and Society 13(3), 343-356

KITCHIN, R., SHIRLOW, P., and SHUTTLEWORTH, I. 1998 'On the margins: disabled people's experience of employment in Donegal, West Ireland' Disability and Society 13(5), 785-806

KLINGER, M. 2002 'Organization culture and people with disabilities' Disability Studies Quarterly 22(1), 21-25

коBAYASH, А. 2002 'A generation later, and still two percent: changing the culture of Canadian geography' The Canadian Geographer 46(3), 245-248

LECK, J.D., ST. ONGE, S., and LALANCETTE, I. 1995 'Wage gap changes among organizations subject to the Employment Equity Act' Canadian Public Policy 21(4), 203-320

LECK, J.D., and SAUNDERS, D. 1996 'Achieving diversity in the workplace: Canada's Employment Equity Act and members of visible minorities' International Journal of Public Administration 19(3), 299-321 
LIEBENS, R. 1998 'The gendering of farming and agricultural politics: a matter of discourse and power' Australian Geographer 29(3), $371-388$

LONGFIELD, J. 2002 Promoting Equality in the Federal Jurisdiction: A Review of the Employment Equity Act, available online at: http://www.parl.gc.ca/InfocomDoc/37/1/HUMA/Studies/Reports/ HUMARP9-e.htm, downloaded August 2002

LONGHURST, R. 2001 'Managing managerial bodies' in Her Bodies: Exploring Fluid Boundaries (London and New York: Routledge) 91-122

mCDowell, L. 1997 Capital Culture: Gender at Work in the City (Oxford: Blackwell)

MORRIS, J. 1991 Pride against Prejudice: Transforming Attitudes to Disability (London: Women's Press)

MOSS, P., and DYCK, I. 1996 'Inquiry into environment and body: women, work and chronic illness' Environment and Planning D: Society and Space 14, 737-753

_. 1999 'Journeying through M.E.: identity, body and women with chronic illness' in Embodied Geographies: Spaces, Bodies and Rites of Passage, ed Elizabeth Kenworthy Teather (New York and London: Routledge) 157-174

NEUFELT, A.H., and FRIIO, s. 1995 'Rights, equity and employment of disabled persons in Canada' in Mandatory Employment or Equal Opportunities? Employment Policies for People with Disabilities in the UN-European Region, eds. K. Leichsenring and C. Strümpel (Vienna: European Centre for Social Welfare and Research) 39-51

OLIVER, M. 1996 Understanding Disability: From Theory to Practice (Basingstoke, UK: Macmillan)

PARR, H., and BUTLER, R. 1999 'New geographies of illness, impairment and disability' in Mind and Body Spaces: Geographies of Illness, Impairment and Disability, eds R. Butler and H. Parr (London and New York: Routledge) 1-24

POOLE, P.-J. 1990 Employment Equity and the Banks: Year II Reports: Disabled Persons (Ottawa: The Canadian Centre for Policy Alternatives and the National Action Committee on the Status of Women)

POOLE, P.-J., and REBICK, J. 1993 'Not another hundred years: the failure of the federal Employment Equity Act' Canadian Labour Law Journal 1, 341-367
RASKIN, c. 1994 'Employment equity for the disabled in Canada' International Labour Review 133(1), 75-88

RESKIN, в. 1993 'Sex segregation in the workplace' Annual Review of Sociology 19, 241-270

RIoux, M.H. 1985 'Labelled disabled and wanting work' in Research studies of the Commission on Equality in Employment, ed R. Abella (Ottawa: Minister of Supply and Services Canada) 613-639

ROEHER INSTITUTE. 1993 On Target? Canada's Employment-related Programs for Persons with Disabilities (Toronto: Roeher Institute)

_. 2001 Disability-related Support Arrangements, Policy Options and Implications for Women's Equality (Toronto: Roeher Institute)

Ross, D., and SHILLING, R. 1990 An Economic Profile of Persons with Disabilities (Ottawa: Canadian Council on Social Development)

SHAKESPEARE, T. ed. 1998 The Disability Reader: Social Science Perspectives (London and New York: Cassell)

STEIN, M.A. 2000 'Labor markets, rationality, and workers with disabilities' Berkeley Journal of Employment and Labor Law 21 , 314-334

THORNTON, P., and LUND, N. 1997 'Employment policies for disabled people in eighteen countries: a review', available online at: http://www.gladnet.org/infobase/empoloyment/Policies/emp_ policies_18_countries.htm, downloaded August 2001

TONKIN, L. 2000 'Women of steel: constructing and contesting new gendered geographies of work in the Australian steel industry' Antipode 32(2), 115-134

WADDINGTON, L., and DILLER, M. 2000 'Tensions and coherence in disability policy: the uneasy relationship between social welfare and civil rights models of disability in American, European and international employment law' (presented at From Principles to Practice: An International Disability Law and Policy Symposium, October 2000) available online at: http://www.dredf.org/ symposium/waddington.html, downloaded December 2001

WILSON, F. 2003 Organizational Behaviour and Gender (Aldershot, Hampshire, UK: Ashgate)

Young, I.M. 1990 Justice and the Politics of Difference. (Princeton, NJ: Princeton University Press) 